\title{
REFERENCES
}

COOPER, G. W.. .
GÄSTRIN, B., KALLINGS, L. O., AND
MARCETIC, A.
REPORT ON THE EFICACY OF WHOOPING
COUGH VACCINES IN THE UNITED
KINGDOM

StUART, R. D. . $\quad$. $\quad$. $\quad$.

StuarT, R. D., Toshach, SHEIla R., AND Patsula, Teresa H.
1957. J. Clin. Path., 10, 226.

1968. Acta path. microbiol. scand., 74, 371.

1969. A preliminary report to the Director of the PHLS by the Whooping Cough Committee and Working Party, in press.

1946. Glasg. Med. J., 27, 131.

1959. Publ. Hlth Rep., Wash., 74, 431.

1954. Canad. J. Publ. Hlth, $45,73$.

\section{AN ACID-FAST BACILLARY PHASE IN STREPTOCOCCUS MG AND CERTAIN OTHER GRAM-POSITIVE COCCI: IDENTIFICATION WITH MYCOCOCCUS (KRASSILNIKOV)}

\author{
Phyllis Pease \\ Department of Bacteriology, University of Birmingham \\ Plate XII
}

STREPTococcus MG is a single strain of Gram-positive coccus isolated from a case of primary atypical pneumonia (Mirick et al., 1944). Its importance lies in the fact that sufferers from this mycoplasma infection develop antibodies to Streptococcus MG (Thomas et al., 1945); and it has been shown that the pathogen, Mycoplasma pneumoniae, shares an antigenic component with the coccus (Marmion and Hers, 1963; Pease, 1963; Eaton, 1965). Streptococcus MG is not supposed to be virulent.

In the process of cultivation of Streptococcus MG in artificial media, it was observed that it possessed the morphological characters of Mycococcus (Krassilnikov). This organism was described by Krassilnikov (1938, cited by Breed, Murray and Smith, 1957, pp. 707-713) and subsequently by Csillag (1964); it is a Gram-positive coccus, characterised by considerable variation in size. The cocci produce rod-like projections that may develop into small mycobacteria. Other strains of unclassified Gram-positive cocci isolated from human sources were found to have the same morphology.

\section{MATERIALS AND METHODS}

The culture of Streptococcus MG employed was NCTC8037. The original observations of the phenomenon were made on a culture from this source that had been maintained freezedried in this department for $4 \mathrm{yr}$. To avoid suspicion of contamination, the observations and illustrations recorded in this paper were made $a b$ initio upon a culture newly obtained from the National Collection of Type Cultures. The identity of this organism was checked at intervals through the project, by slide-agglutination with Burroughs Wellcome Streptococcus MG antiserum, batch K7645.

Strains of Gram-positive cocci, S47, C20 and C25, were isolated in this laboratory from human serum, in the course of a general investigation.

Nutrient agar and nutrient broth (Oxoid) were autoclaved at $121^{\circ} \mathrm{C}$ for $15 \mathrm{~min}$. Cultures 
ACID-FAST BaCILl AND STREPTOCOCCUS MG

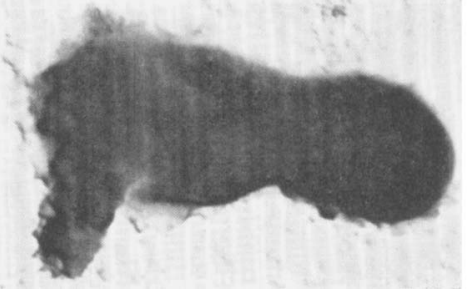

FIG. 1.-Double coccus with early stage of projecting rod.

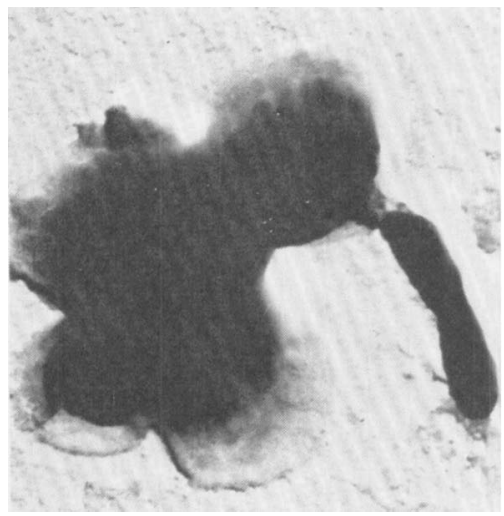

FIG. 3.-Tetrad with complete: curved bacillus attached.

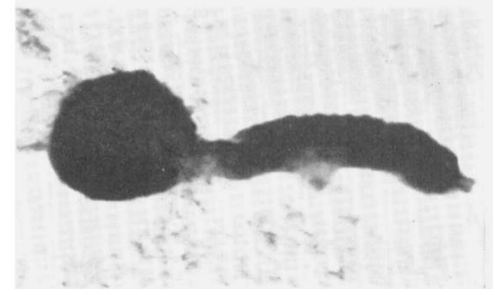

FrG. 2.-Single coccus with complete, curved bacillus attached.

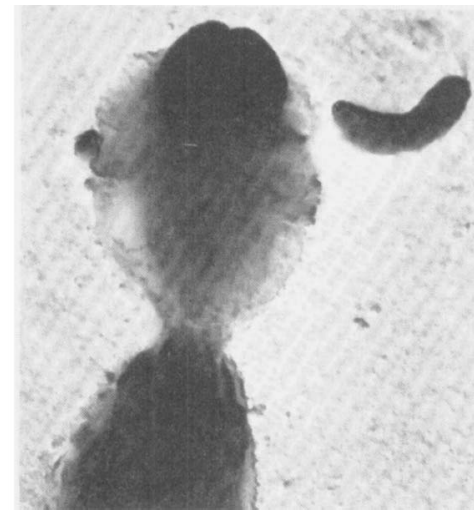

FIG. 4.-End of chain of cocci with small, curved bacillus, almost free.

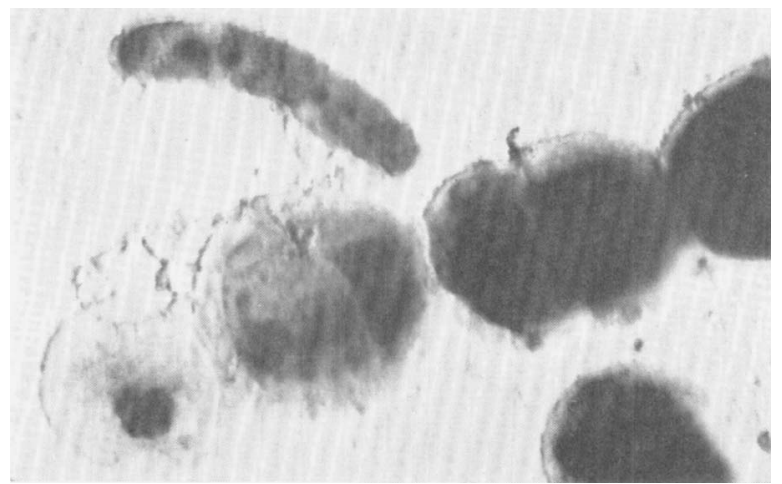

FIG. 5.-Chain of cocci with bacillus, almost free.

FIGS. 1-5.- Streptococcus MG in subcultures grown on nutrient agar for between $24 \mathrm{hr}$ and $6 \mathrm{wk}$ at $37^{\circ} \mathrm{C}$ after inoculation from a culture grown in nutrient broth for $24 \mathrm{hr}$. Electron micrographs. $\times 25,000$. 
were incubated at $37^{\circ} \mathrm{C}$. Fermentation and other cultural tests were performed by standard methods (Cowan and Steel, 1965). Resistance to sulphadimidine was determined by the observation of absence of a zone of inhibition around a $200 \mathrm{mg}$ disk of sulphadimidine on a lawn of growth on a nutrient agar plate.

Acid-fastness was tested by a modified Ziehl-Neelsen stain with decolorisation for 2 min. in 5 per cent. $\mathrm{H}_{2} \mathrm{SO}_{4}$ and for $15 \mathrm{~s}$ in 90 per cent. ethanol. Material for electron microscopy was suspended in sterile distilled water, and gold-palladium shadowed on the grid. The media and distilled water were examined repeatedly during the course of the experiment, by electron microscopy, for the presence of contaminating bacteria similar to those under investigation.

\section{RESULTS}

Cultures of Streptococcus MG in both solid and fluid media were observed at ages from $24 \mathrm{hr}$ to $6 \mathrm{wk}$. The organism was repeatedly plated and single colonies subcultured, and the observations described below were made on several different lines of subcultures. Cocci were

TABLE

Physiological characters of Streptococcus $M G$ and of strains of Gram-positive cocci from human serum

\begin{tabular}{|c|c|c|c|c|}
\hline \multirow{2}{*}{ Character } & \multicolumn{4}{|c|}{ Organism } \\
\hline & $\begin{array}{c}\text { Streptococcus } \\
\text { MG }\end{array}$ & $\underset{\text { Strain }}{\text { St7 }}$ & $\begin{array}{c}\text { Strain } \\
\text { C20 }\end{array}$ & $\underset{\text { C25 }}{\text { Strain }}$ \\
\hline $\begin{array}{l}\text { Acid production from: } \\
\text { dulcitol } \\
\text { glucose } \\
\text { lactose } \\
\text { maltose } \\
\text { mannitol } \\
\text { sucrose }\end{array}$ & $\begin{array}{l}\overline{+} \\
+ \\
+ \\
+ \\
+\end{array}$ & $\begin{array}{l}\overline{+} \\
\overline{+} \\
\frac{+}{+}\end{array}$ & $\begin{array}{l}\overline{+} \\
\overline{+} \\
+ \\
+ \\
+\end{array}$ & $\begin{array}{l}\overline{+} \\
\overline{+} \\
\dot{+} \\
+\end{array}$ \\
\hline $\begin{array}{l}\text { Coagulase reaction } \\
\text { Gelatin hydrolysis } \\
\text { Haemolysis (horse blood) } \\
\text { Methyl red reaction } \\
\text { Serum liquefaction } \\
\text { Sulphadimidine resistance }\end{array}$ & $\begin{array}{l}- \\
\overline{-} \\
\frac{+}{+} \\
+\end{array}$ & $\begin{array}{l}- \\
- \\
- \\
\bar{t} \\
+\end{array}$ & $\begin{array}{l}\overline{-} \\
\overline{-} \\
\overline{-} \\
\overline{+}\end{array}$ & $\begin{array}{l}- \\
\overline{-} \\
\overline{-} \\
\overline{+}\end{array}$ \\
\hline
\end{tabular}

$t=$ Acid produced, or positive reaction. No strain produced gas in fermenting carbohydrates. $-=$ Acid not produced, or negative reaction.

Gram-positive and varied in diameter from $c .0 \cdot 2$ to $c .2 \cdot 5 \mu \mathrm{m}$, at all stages of culture, but the proportion of cocci of normal appearance, $c .0 .6 \mu \mathrm{m}$ in diameter, which resembled small streptococci, was high in young cultures. Cocci with budding rodlets were observable at all stages of culture, both with the electron microscope and, in wet films, with the light microscope, but were extremely rare on solid medium before $c .1 \mathrm{wk}$. In subcultures on solid medium from cultures grown for $24 \mathrm{hr}$ in fluid medium, these forms developed freely and rapidly, so that the cultures contained from 1 to 5 per cent. of budding cocci and considerable numbers of small bacilli. Many of the budding cocci were disposed in pairs, chains and loose tetrads (figs. 1-3). The bacilli were markedly curved, especially when lying free (figs. 4 and 5). Both the buds and the bacilli were markedly opaque to the electron beam; some were acid-fast to 5 per cent. $\mathrm{H}_{2} \mathrm{SO}_{4}$, but the proportion of acid-fast forms was variable in different preparations. 
Attempts to isolate the bacillary form in pure culture have not so far been successful. They appeared to increase in size and revert to the coccal phase by a process that has not yet been clearly illustrated.

Three strains of unclassified Gram-positive cocci isolated from human serum were examined in the same manner and found to undergo the same morphological changes. Their cultural characters were compared with those of Streptococcus MG, and the results are shown in the table. Their colonies on agar were larger and more opaque than those of Streptococcus MG, but they were culturally similar in other respects, except that they failed to ferment lactose. Acid-fastness was most notable in strain S47.

\section{Discussion}

The observations illustrated in this paper are concerned with a type of bacterial growth that has been very little studied, but has, nevertheless, been recorded on several occasions. Very similar descriptions of changes from Gram-positive cocci to acid-fast bacteria were published by Lindegren and Mellon (1932), Mellon, Richardson and Fisher(1932), AlexanderJackson (1954) and Spassky (1933), who was considered by Krassilnikov (1938, cited by Breed et al., 1957, p. 709) to have been dealing with a strain of Mycococcus. The range of variation in size of the cocci I examined is characteristic of Mycococcus, as described by Krassilnikov. The resistance of all the strains to sulphadimidine is also of interest, since resistance to sulphonamides is an important character of Streptococcus MG that serves to distinguish it from similar Gram-positive cocci (Breed et al., 1957, p. 529).

Contamination cannot be adduced to account for these phenomena, which were observed only in comparable strains of Gram-positive cocci, among the very many bacteria cultured and examined by electron microscopy in this laboratory. Acid-fast variants appeared in cultures made immediately from authenticated strains of Streptococcus MG, under stringently controlled conditions. The bacillary forms could be observed in electron micrographs to be emerging from the coccal stages, and the fully formed rods were frequently still attached. This conforms with Krassilnikov's description of " germ tubes ". No trace of contaminating bacteria was found in repeated examinations of materials employed, including distilled water, which is sometimes quoted as a possible source of error in respect of acid-fast bacteria.

\section{SUMMARY}

Streptococcus MG has been found to pass through a growth phase previously described for Mycococcus (Krassilnikov). The Gram-positive cocci, in the course of prolonged culture, become variable in size, and produce projections which develop into weakly acid-fast rods. Comparable Gram-positive cocci, isolated from human serum, showed a similar variation.

\section{REFERENCES}

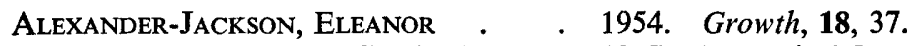

Breed, R. S., Murray, E. G. D., AND 1957. Bergey's Manual of determinative bacSMITH, N. R.

Cowan, S. T., AND Steel, K. J. teriology, 7th ed., Baltimore.

Csillag, AnNa . $\quad . \quad$. $\quad$. $\quad$. 1964. J. Gen. Microbiol., 34, 341.

EATON, M. D. . . . . . . . 1965. A. Rev. Microbiol., 19, 379.

Lindegren, C. C., ANd Mellon, R. R. . 1932. Proc. Soc. Exp. Biol. Med., 30, 110.

Marmion, B. P., and Hers, J. F. P. $\quad$. 1963. Amer. Rev. Resp. Dis., Suppl. 88, p. 198.

Mellon, R. R., Richardson, R. D., AND 1932. Proc. Soc. Exp. Biol. Med., 30, 80.

FISHER, L. W.

Mirick, G. S., Thomas, L., Curnen, 1944. J. Exp. Med., 80, 391, 407 and 431.

E. C., AND Horsfall, F. L.

Pease, Phyllis E. $\quad$ - $\quad$ - $\quad$. $\quad$ 1963. Nature, Lond., 197, 1132. 
Spassky, M. N. . 1933. Zentbl. Bakt. ParasitKde, Abt. I, Orig., $128,245$.

Thomas, L., Mirick, G. S., Curnen, 1945. J. Clin. Invest., 24, 227.

E. C., Ziegler, J. E., AND Horsfall,

F. L.

\title{
BACTERIA IN RENAL CASTS
}

\author{
S. T. G. ButTeRWORTH \\ Department of Pathology, Western General Hospital, Edinburgh
}

BACTERIA are often found closely applied to the surface of renal casts in urine, sometimes in large numbers. Less frequently they can be observed within the substance of the cast, where their position can be confirmed by careful focusing. Occasionally they are seen within polymorphonuclear leucocytes incorporated in casts, but since in casts these cells are always rather shrunken the contained bacteria cannot be identified easily. The presence of bacteriumlike structures in casts does not appear to have been previously recorded.

\section{MATERIALS AND METHODS}

During an assessment of the value of various methods of staining the urine sediment (Butterworth, 1969), bacterium-like structures were observed in casts stained with cadmiummethylene blue. Thereafter, over 400 urine specimens were examined by the same method, and any casts seen were examined under the oil-immersion objective for the presence of similar structures.

Cast protein and Tamm-Horsfall protein were prepared by the methods of McQueen (1962). For measurement of antibacterial activity, a saturated solution of Tamm-Horsfall protein was made by shaking an excess with $0.5 \mathrm{ml}$ of distilled water and allowing it to stand overnight. A saturated solution of cast protein was prepared in the same way. The supernatants were added to $0.5-\mathrm{ml}$ volumes of a suspension of Escherichia coli in peptone water containing approximately 10 organisms per $\mathrm{mm}^{3}$, and a control tube was prepared containing the same suspension and an equal volume of distilled water. The three tubes were incubated at $37^{\circ} \mathrm{C}$ for $16 \mathrm{hr}$, after which the numbers of bacteria present in each suspension were estimated by counting, after appropriate dilution, in a Neubauer chamber.

\section{RESULTS}

The phenomenon was observed in only ten cases, which are listed in the table. The diagnosis of chronic pyelonephritis was based on the evidence of quantitative cell counts and radiography; in case no. 2, quantitative bacteriological examination of the urine supplied additional evidence. The diagnoses in cases no. 5 and 10 were confirmed at post-mortem examination and in case no. 9 by percutaneous biopsy. Samples of urine from more than 100 further patients with probable pyelonephritis failed to show bacteria in casts; in most cases no casts were present.

In a predominantiy granular cast, the granular material takes up the stain, whereas the hyaline matrix does so only faintly and any contained structures can be seen. Usually the structures were rods, but in cases no. 5 and 9 they were cocci. They bore such a close resemblance to bacteria outside the casts that there is little reasonable doubt that they were bacteria. 